\title{
Ovariectomy as a therapeutic principle for ovarian disorders in horses - Indication, surgical procedures and results
}

\author{
Claus Peter Bartmann ${ }^{1,2}$,Viola Schiemann', Christin Ellenberger ${ }^{3}$, Hans-OHo Hoppen ${ }^{4}$ und Heinz-Adolph Schoon ${ }^{3}$ \\ Klinik für Pferde, Tierärztliche Hochschule Hannover', Einsatz- und Ausbildungszentrum für Gebirgstragtienwesen 230, Bad Reichenhall2, Institut für Veterinär- \\ Pathologie, Universität Leipzig ${ }^{3}$ und Zentrumsabteilung für Chemische Analytik und Endokrinologie, Tierärztliche Hochschule Hannover ${ }^{4}$
}

\begin{abstract}
Summary
During the six year period between 1996 and 2002, 45 mares underwent unilateral ovariectomy as a result a of diagnosis of ovarian neoplasia, abscess, haematoma or dystrophia. Diagnosis was based on the results of observed behaviour, clinical, ultrasonographical and endocrinological (circulating levels of $T, E_{2}, P_{4}$ ) examination, and by collection and patho- and immunohistological examination of endometrium biopsy specimens. Typical findings in mares with postoperatively confirmed granulosa cell tumour included stallion-like behaviour, unilateral enlargement of the affected ovary with atrophy of the inhibited contralateral ovary and various abnormalities in the ultrasonographical appearance of the neoplastic ovary. Serum testosterone levels were remarkably elevated in only 19 of the 35 mares with granulosa cell tumor prior to ovariectomy. Surgical procedures included the flank approach by modified grid technique or the ventral midline approach with exteriorisation and complete resection of the affected ovary under general anaesthesia, or laparoscopy in the standing mare. Pathohistological examination of the 45 ovaries revealed 35 granulosa cell tumours, two teratomas, one thecoma, one cystadenoma, one ovarian abscess, one ovarian haematoma, one corpus luteum cyst, one stromal metaplasia and one stromal thecosis. With only two exceptions, even those granulosa cell tumours which remained clinically and endocrinologically unclear were associated with an endometrial maldifferentiation (EMD), possibly indicating a hormonal activity of the tumour cells. Endometrial maldifferentiation may indicate hormonal disturbances. It also serves as a distinct bio-assay which is available prior to surgery. In addition to clinical, ultrasonographic and endocrinological findings, endometrial biopsy is a useful aid in the evaluation of abnormal ovaries. Follow-up results for 32 mares regarding reestablishment of fertility and cessation of irregular behaviour were judged to be good, particularly following resection of a granulosa cell tumour. All those mares developed normal behaviour postoperatively and 13 of the 14 mares that were mated or inseminated conceived and reached parturition.
\end{abstract}

Keywords: horse, ovary, ultrasonography, endometrium, maldifferentiation, ovariectomy

Die Ovariekomie als therapeutisches Prinzip bei ovariellen Erkrankungen des Pferdes - Indikationen, chirurgische Durchführung und Ergebnisse

In der Klinik für Pferde wurden in den Jahren 1996 bis 2002 insgesamt 45 Stuten mit einer Erkrankung eines Eierstockes einer unilateralen Ovariektomie unterzogen. Grundlegende Erkrankungen des Eierstockes waren ovarielle Neoplasien, Abszesse, Hämatome sowie dystrophische Abweichungen. Die gynäkologische Untersuchung der Stuten beinhaltete neben der klinischen und ultrasonographischen Beurteilung auch die Bestimmung der peripheren Sexualsteroide $\left(E_{2}, T, P_{4}\right)$ sowie die Entnahme und patho- und immunhistologische Untersuchung einer Endometriumbiopsie. Bei Stuten mit einer ovariellen Neoplasie war in der Mehrzahl der Fälle neben einem Megaovar bei kontralateraler Ovaratrophie und einer Azyklie eine uneinheitlich abweichende Echotextur des neoplastischen Eierstockes auffällig. Jedoch waren vier Stuten normozyklisch und bei sechs Stuten konnte keine Atrophie des kontralateralen Ovars ermittelt werden. Die Serumtestosteronwerte waren vor der Ovariektomie bei lediglich 19 der 35 Stuten mit Granulosazelltumor deutlich erhöht. Bei allen Stuten wurde das veränderte Ovar unter Allgemeinanästhesie über einen Zugang in der Flanke oder der Linea alba bzw. am stehenden Tier laparoskopisch entfernt. Die patho-histologische Untersuchung dieser Eierstöcke ergab in 35 Fällen einen Granulosazelltumor, zwei Teratome und jeweils einmal ein Thekom und ein Zystadenom. Darüber hinaus lagen je einmal ein Ovarhämatom, ein Ovarabszeß, eine Gelbkörperzyste, eine stromale Thekose und eine stromale Metaplasie vor. Als regelmäßiger Befund auch bei klinisch und endokrinologisch weitgehend maskierten Granulosazelltumoren wurde vor der Operation durch patho-histologische Untersuchung von Endometriumbiopsien eine irreguläre endometriale Differenzierung erkannt. Diese kann als Ausdruck einer durch den Eierstocktumor vermittelten hormonellen Imbalance gewertet werden, welche somit direkt am Erfolgsorgan bereits vor der Ovariektomie diagnostisch erfaßt werden kann. Damit ist die Beurteilung einer Endometriumbiopsieprobe in Ergänzung zu klinischen, sonographischen und endokrinologischen Untersuchungstechniken ein hilfreiches und sensibles Verfahren bei der diagnostischen Abklärung pathologischer Zustände des Pferdeovars. Bezüglich der Wiederherstellung der Fertilität und der Normalisierung abweichenden Verhaltens ergaben sich in einer Langzeitüberprüfung vor allem für Stuten nach Resektion eines Granulosazelltumors gute Ergebnisse. Alle diese Stuten zeigten eine Verhaltensnormalisierung innerhalb kurzer Zeit. Von 14 erneut zur Zucht eingesetzten Stuten fohlten 13 mindestens einmal bereits ab.

Schlüsselwörter: Reproduktion, Stute, Ovar, Sonographie, Endometrium, Ovariektomie

\section{Introduction}

Surgical diseases of the equine ovary include ovarian neoplasia, abscess, haematoma or torsion. Neoplasia of the equine ovaries may lead to infertility and severe behavioural problems such as stallion-like behaviour or permanent estrus
(Meinecke 1986; Stabenfeldt et al. 1979). Ovarian abscess can be the result of ascending infection or invasive procedures with participation of the ovary. Ovarian torsion has been reported only in a few cases in which the mares showed symptoms of colic (Valk et al. 1998). 
For successful therapy, the diseased ovary has to be removed surgically. Ovariectomy is a relatively common surgical procedure in the mare with ovarial neoplasia the most typical indication but there may be a high frequency of complications for an elective operation (Nickels 1988; Meagher et al. 1978). For this reason, a definite diagnosis should be obligatory prior to surgery. This might be difficult, particularly for ovarian neoplasia due to the large variety in its clinical and endocrinological presentation (Meagher et al. 1978; Nickel 1988; Slone 1988). Specificity of preoperative diagnosis has been described as very low, with $40 \%$ for the most common granulosa cell tumour (Herfen et al. 1996).

In addition to clinical techniques, sonographic and endocrinological methods are well established in the diagnosis of ovarian disorders (Hinrichs and Hunt 1990; Hoppen 1995, Watson 1999). Nevertheless, it may remain difficult to differentiate between ovarian disorders characterised by an enlargement such as ovarian neoplasia from other diseases such as ovarian haematoma or functional disturbances. Spontaneous endometrial maldifferentiation in the mare has been described by Schoon et al. $(1999,2000)$ who found it to be associated with hormonal imbalances.

Likewise, ovarian neoplasia, particularly granulosa cell tumours, can be associated with hormonal imbalances (Bailey et al. 1999, Meinecke and Gips 1987) and may lead to endometrial maldifferentiation (Ellenberger et al. 2002). Ovariectomy in the mare can be performed using a flank approach, ventro-median or diagonal-paramedian approach (Carson-Dunkerley and Reid-Hanson 1997, Herfen et al. 1996; Meagher et al. 1978). Operative laparoscopy is a common technique for bilateral ovariectomy in the healthy mare (Palmer 1993) but was even considered a reliable technique for resection of neoplastic ovaries (Röcken 2000) as well.

Ovarian disorders in the neonatal foal are extremely rare and are typically obvious during a diagnostic laparotomy.

Depending on the type of ovarian disorder, the purpose of an unilateral ovariectomy can be the reestablishment of general condition and fertility or the normalization of hormonally influenced irregular behaviour.

\section{Material and methods}

Horses

During a six year period between 1996 and 2002, 45 mares underwent an unilateral ovariectomy after of diagnosis of ovarian disorders. The horses were of different breeds (35 warmblooded horses, 4 Arabian, 4 Ponies, 1 Friesian, 1 Trotter) and ages (between four days and 13 years). Of the 44 adult mares, 23 had foaled up to four times.

The reason for referral was unilateral ovarian enlargement found by transrectal palpation, infertility or abnormal, stallion-like or aggressive behaviour, permanent oestrus or refusal to be ridden. In one mare, unilateral ovarian enlargement was associated with febrile peritonitis. The only foal in this study was referred with a history of acute colic symptoms. Details are given in Table 1 .

\section{Patient examination}

Diagnosis was based on case history, clinical presentation and a complete gynecological examination. Before surgery, the following blood profile was evaluated: packed cell volume (PCV), haemoglobin (Hb), total plasma protein (TPP), white blood cell count (WBC), activated partial thromboplastin time (APTT), thrombin time (TT).

Following clinical observation of the sexual behaviour of the mares with a mare in oestrus present, the ovaries were examined by transrectal palpation and sonography with a 5.0 or 7.5 MHz linear probe (Aloka SSD 210, $5 \mathrm{MHz}$, Hellige, Germany, or Sonoline Versa Pro, $7.5 \mathrm{MHz}$, Siemens, Germany). Vaginal examination was performed with a Polansky speculum. In addition, an endometrial biopsy was taken transcervically in 35 of the 45 mares with a Ferris biopsy forceps. The specimens were fixed in buffered $4 \%$ formalin, routinely embedded in paraplast, stained with haemotoxylin-eosin (H.E.) and examined patho-histologically according to Schoon et al. (1997; 2000).

Blood samples were collected from the jugular vein and the serum steroids testosterone $(T)$, estradiol $\left(E_{2}\right)$ and progesterone $\left(\mathrm{P}_{4}\right)$ were determined by radioimmunoassay as described by Hoppen (1995).

Explorative laparotomy was the base of diagnosis in the only foal with ovarian disorder in this study (Fig. 1).

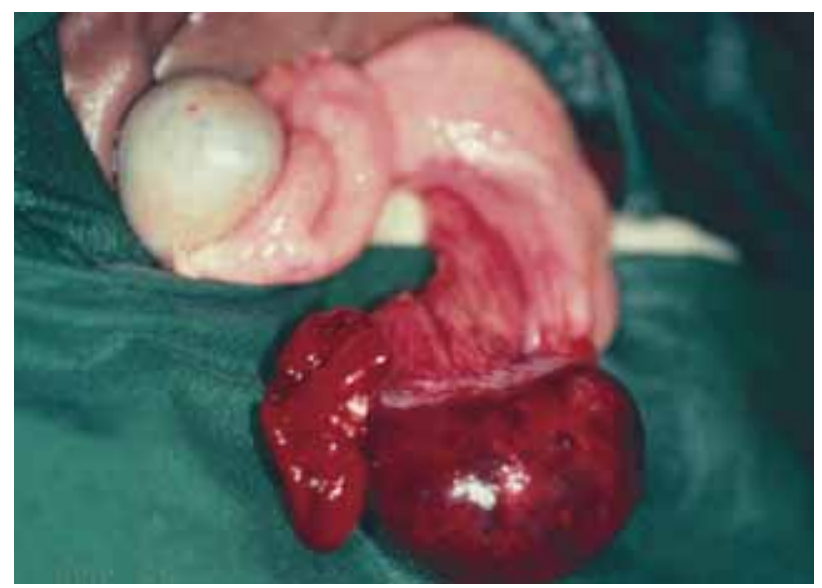

Fig 1 Intraoperative finding of an ovarian torsion in a filly. The contralateral, healthy ovary is smaller and completely white. Intraoperativer Befund einer Ovartorsion bei einem neonaten Fohlen. Das kontralaterale, gesunde Ovar stellt sich kleiner und weiß dar.

\section{Surgical procedures}

Probiotics were added to the food pre- and postoperatively over a seven-day period. Food was withheld from all the mares 9 to 12 hours before surgery.

Surgical procedures were performed under general anaesthesia except in those horses upon which operative laparoscopy was performed. Here, ovariectomy was done as described by Palmer (1993), Röcken (2000) or Bartmann and Lorber (in press).

For general anaesthesia, mares were sedated with intravenous administration of $1.1 \mathrm{mg} / \mathrm{kg}$ bw xylazine (Rompun ${ }^{\circledR}$, Bayer Vital, Leverkusen Germany). Anaesthesia was induced with intravenous administration of $2.2 \mathrm{mg} / \mathrm{kg}$ bw ketamin (Narketan ${ }^{\circledR}$, Chassot, Ravensburg, Germany) and 0.05 $\mathrm{mg} / \mathrm{kg}$ Diazepam (Diazepam, Ratiopharm, Ulm, Germany) 


\begin{tabular}{|c|c|c|c|c|c|c|c|c|}
\hline \multirow[t]{3}{*}{ No. } & \multirow{3}{*}{$\begin{array}{l}\text { Sonographic } \\
\text { findings }\end{array}$} & \multirow{3}{*}{$\begin{array}{c}\text { Contra } \\
\text { lat. } \\
\text { ovarian } \\
\text { atrophy }\end{array}$} & \multicolumn{4}{|c|}{ Serum steroids } & \multirow{3}{*}{$\begin{array}{l}\text { Histological } \\
\text { findings } \\
\text { endometrium }\end{array}$} & \multirow{3}{*}{$\begin{array}{c}\text { Histological } \\
\text { findings ovary }\end{array}$} \\
\hline & & & \multicolumn{2}{|c|}{$T(\mathrm{ng} / \mathrm{ml})$} & \multicolumn{2}{|c|}{$E_{2}(\mathrm{pg} / \mathrm{ml})$} & & \\
\hline & & & $\begin{array}{l}\text { Pre } \\
\text { op. }\end{array}$ & $\begin{array}{l}\text { Post } \\
\text { op. }\end{array}$ & $\begin{array}{l}\text { Pre } \\
\text { op. }\end{array}$ & $\begin{array}{l}\text { Post } \\
\text { op. }\end{array}$ & & \\
\hline 1 & Multiple cysts & Yes & 0.04 & - & 10 & - & - & GCT \\
\hline 2 & High Density & Yes & 0.07 & 0.01 & 12 & 7 & - & GCT \\
\hline 3 & Multiple cysts & Yes & 0.04 & 0.01 & 12 & 4 & - & GCT \\
\hline 4 & Solitary cyst & No & 0.06 & - & 44 & - & - & GCT \\
\hline 5 & Large cysts & Yes & 0.06 & - & 25 & - & - & GCT \\
\hline 6 & Multiple cysts & No & 0.08 & 0.01 & 30 & 7 & EMD & GCT \\
\hline 7 & Honeycomb & Yes & 0.18 & 0.02 & 12 & 7 & - & GCT \\
\hline 8 & Honeycomb & Yes & 0.03 & 0.01 & 11 & 10 & EMD & GCT \\
\hline 9 & Multiple cysts & Yes & 0.05 & 0.01 & 13 & 1 & - & GCT \\
\hline 10 & Multiple cysts & Yes & 0.11 & 0.01 & 5 & 1 & - & GCT \\
\hline 11 & Multiple cysts & Yes & - & - & - & - & Normal & GCT \\
\hline 12 & Multiple cysts & Yes & 0.14 & - & 16 & - & EMD & GCT \\
\hline 13 & Multiple cysts & Yes & 0.03 & 0.01 & 5 & 5 & EMD & GCT \\
\hline 14 & Multiple cysts & Yes & 0.19 & 0.01 & 27 & 5 & EMD & GCT \\
\hline 15 & Multiple cysts & Yes & 0.03 & - & 16 & - & EMD & GCT \\
\hline 16 & Multiple cysts & Yes & 0.02 & 0.01 & 1 & 4 & EMD & GCT \\
\hline 17 & Honeycomb & Yes & 0.02 & 0.01 & 3 & 5 & EMD & GCT \\
\hline 18 & Multiple cysts & Yes & 0.01 & - & 20 & - & EMD & GCT \\
\hline 19 & Honeycomb & Yes & 0.08 & 0.01 & 9 & 5 & Inactive & GCT \\
\hline 20 & Solitary cyst & Yes & 0.01 & 0.01 & 5 & 5 & EMD & GCT \\
\hline 21 & Honeycomb & No & 0.03 & 0.01 & 8 & 5 & EMD & GCT \\
\hline 22 & Large cysts & Yes & 0.03 & 0.01 & 8 & 5 & EMD & GCT \\
\hline 23 & Solid, echogenous & Yes & 0.36 & 0.01 & 6 & 5 & EMD & GCT \\
\hline 24 & Large cysts & Yes & 0.01 & 0.01 & 7 & 5 & EMD & GCT \\
\hline 25 & Solid, echogenous & Yes & 0.04 & 0.01 & 5 & 3 & EMD & GCT \\
\hline 26 & Honeycomb & Yes & 0.04 & 0.01 & 12 & 7 & EMD & GCT \\
\hline 27 & Solid, echogenous & Yes & 0.05 & 0.01 & 8 & 5 & EMD & GCT \\
\hline 28 & Multiple cysts & Yes & 0.39 & 0.01 & 26 & 1 & EMD & GCT \\
\hline 29 & Multiple cysts & No & 0.1 & 0.01 & 30 & 4 & EMD & GCT \\
\hline 30 & Multiple cysts & Yes & 0.1 & 0.01 & 15 & 6 & EMD & GCT \\
\hline 31 & High density & Yes & 0.14 & 0.01 & 23 & 8 & Normal & GCT \\
\hline 32 & Honeycomb & Yes & 0.5 & 0.01 & 23 & 2 & EMD & GCT \\
\hline 33 & High density & Yes & - & - & - & - & - & GCT \\
\hline 34 & Multiple cysts & Yes & 0.1 & 0.01 & 13 & 2 & EMD & GCT \\
\hline 35 & High density & Yes & 0.2 & 0.01 & 18 & 4 & EMD & GCT \\
\hline 36 & Not uniformous & No & 0.02 & 0.01 & 3 & 4 & Gland. atrophy & Malignant Teratoma \\
\hline 37 & Large cyst & No & 0.01 & 0.01 & 25 & 13 & Normal & Teratoma \\
\hline 38 & Multiple cysts & No & 0.04 & 0.01 & 10 & 9 & EMD & Thecoma \\
\hline 39 & Solitary cyst & No & 0.01 & 0.01 & 12 & 9 & Normal & Cystadenoma \\
\hline 40 & Hyperechogenic & No & 0.03 & 0.02 & 7 & 5 & EMD & Stromal metaplasia \\
\hline 41 & Hyperechogenic & No & 0.01 & 0.01 & 6 & 12 & EMD & $\begin{array}{c}\text { Stromal } \\
\text { hyperthecosis }\end{array}$ \\
\hline 42 & Hyperechogenic & No & 0.02 & 0.01 & 25 & 23 & Down regulation & Corpus luteum cyst \\
\hline 43 & - & No & - & - & - & - & - & $\begin{array}{c}\text { Ovarian torsion and } \\
\text { hematoma }\end{array}$ \\
\hline 44 & Large cyst & No & 0.01 & 0.01 & 13 & 9 & Normal & Ovarian hematoma \\
\hline 45 & $\begin{array}{l}\text { Hyperechogenic capsule } \\
\text { formation }\end{array}$ & No & 0.01 & - & 10 & - & - & Ovarian abscess \\
\hline
\end{tabular}

Tab 1 Ultrasonographic, endocrinological (testosterone T, estradiol $\left.E_{2}\right)$ and patho-histological (endometrium and ovary) findings in 45 mares with unilateral ovariectomy.

EMD: Endometrial maldifferenciation, GCT: Granulosa cell Tumour, -: not examined

Sonographische, endokrinologische (Testosteron T, Ostradiol E2) und patho-histologische Befunde (Endometrium und Ovar) von 45 Stuten mit unilateraler Ovariektomie. and maintained following intubation as inhalation anaesthesia with oxygenised halothane (Halothan ${ }^{\circledR}$, Hoechst Roussel, Unterschleißheim, Germany) or isofluran (Isoflo ${ }^{\circledR}$, Essex, München, Germany). Perioperative treatment included low dose heparinisation (Gerhards 1991), intravenous application of $20 \mathrm{mg} / \mathrm{kg}$ bw sulfonamid/trimethoprim $\left(\right.$ Borga $^{\circledR}$, Intervet, Unterschleißheim, Germany) or $10 \mathrm{mg} / \mathrm{kg}$ bw amoxicillin (Amoxicillin pro inj., Serumwerk Bernburg, Bernburg, Germany) and $1.1 \mathrm{mg} / \mathrm{kg}$ bw flunixin meglumine (Finadyne ${ }^{\circledR}$, Essex, München, Germany).

During surgery, mares were monitored clinically, with blood gas analysis and electrocardiogram and arterial blood pressure was controlled continuously throughout surgery and stabilised at more than $60 \mathrm{~mm} \mathrm{Hg}$ with intravenous infusion of crystalloid fluids and dobutamine 1.5 (g/ kg/min). The mares were positioned in lateral ( $n=39$ ) or dorsal $(n=3)$ recumbency depending on the size of the ovary to be exstirpated. As well depending on the volume of the neoplastic ovary, a flank approach was obtained using a modified grid technique or a through-and through-incision. A caudal ventral midline approach was performed when the ovary was of excessive size. After exteriorisation of the ovary, the mesovarium was ligated step by step (Dexon ${ }^{\circledR} 5$ metric) before dissection. Haemostasis was controlled carefully and the abdominal incision was sutured in layers.

Postanaesthetic sedation was obtained by intravenous administration of $0.2 \mathrm{mg} / \mathrm{kg}$ bw xylazine (Rompun ${ }^{\circledR}$, Bayer Vital, Leverkusen Germany) immediately after extubation. 
Postoperative treatment and follow-up

Postoperative heparinisation was continued for six days. Antibiotic and antiphlogistic medication described above was continued for three days. Probiotics were added to the food to stabilise the caecal flora and to avoid dysbiosis and typhlocolitis. The mares were monitored closely by clinical evaluation and blood tests (PCV, HB, WBC, TPP, APTT, TT).

Prior to release from the clinic, the mares underwent another gynaecological examination, including transrectal palpation, sonography, endocrinological testing and collection of an endometrial biopsy. The resected ovaries were fixed in buffered formalin and examined patho-histologically.

Follow-up information on long-term survival, fertility, reproduction state, behaviour and riding performance was obtained by telephone contact with the owners of the mares.

\section{Results}

Gynaecological examination

Unilateral ovarian enlargement was registered in 40 of the 45 mares. In comparison to healthy mares, the echotexture of the diseased ovary was abnormal in 43 mares (Table 1). In mares with granulosa cell tumour, the echotexture was a multiple cyst-like (Fig. 2), honeycomb-like or solid (Fig. 3).

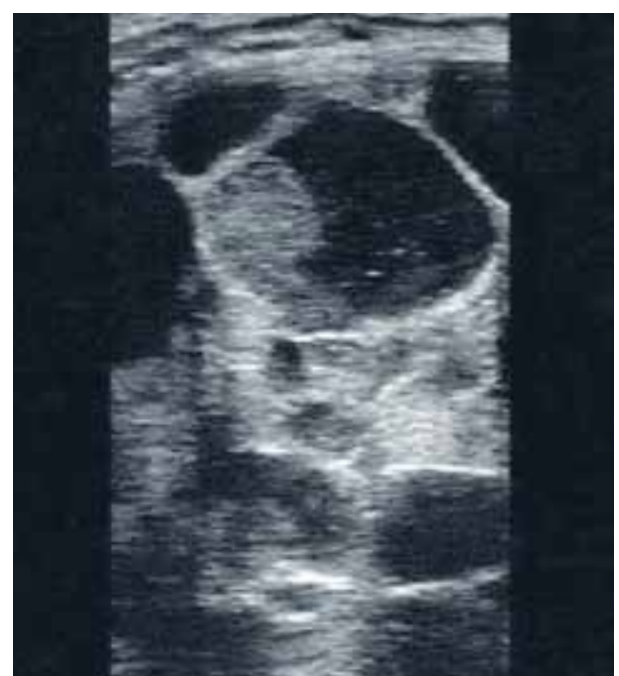

Fig 2 Sonography of a multi cyst-like granulosa cell tumour. Sonographische Darstellung (7.5 Mhz) eines multizystischen Granulosazelltumors.

Atrophy of the contralateral ovary was registered in 31 of the 35 mares with a granulosa cell tumour but not in any of the other mares. Mares with granulosa cell tumour but without contralateral ovarian atrophy (Nos. 4, 6, 21, and 29) showed a clinically normal sexual cycle or permanent oestrus symptoms.

Prior to surgery, the serum level of testosterone ranged from 0.01 to $0.5 \mathrm{ng} / \mathrm{ml}$ and the level of estradiol ranged from 3 to $44 \mathrm{pg} / \mathrm{ml}$ in mares with a granulosa cell tumor. Ten days after unilateral ovariectomy, levels of testosterone and estradiol decreased in all those mares to below $0.04 \mathrm{ng} / \mathrm{ml}$ or 10 $\mathrm{pg} / \mathrm{ml}$, respectively. In horses with other ovarian neoplasia or different disorders, serum testosterone and serum estradiol did not exceed $0.02 \mathrm{ng} / \mathrm{ml}$ or $25 \mathrm{pg} / \mathrm{ml}$, respectively.
In all mares with a granulosa cell tumour except mares Nos. 11 and 31, histological, immunohistological and biochemical examination of the endometrial biopsy revealed varying types and degrees of endometrial maldifferentiation, characterised by an irregular glandular differentiation, low proliferation activity and discontinous glandular basement membranes. Endometrial maldifferentiation was also found in mares with malignant teratoma, thecoma, stromal metaplasia or stromal hyperthecosis.

No maldifferentiation was obvious in mares with a cystadenoma, a benign teratoma or with ovarian abscesses or haematoma (Table 1). Ten days following surgery, a more regular endometrial differentiation was registered indicating in part the beginning of normalisation of the endometrial morphology.

\section{Surgical procedures}

In one mare, multiple metastasis of an ovarian teratoma (No. 36) was found (Fig. 4): the surgery was then aborted and the horse was euthanized. Intraoperative finding of generalised peritonitis with severe adhesion formation was the reason for euthanisation of another mare (No. 45) found during laparotomy to have an ovarian abscess (Fig. 5). In all other mares, surgical procedures were completed without intraoperative complications.

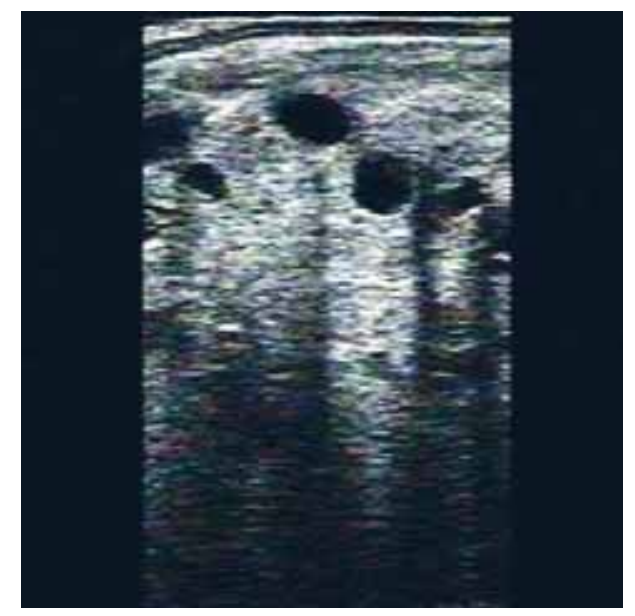

Fig 3 Sonography of a solid granulosa cell tumour. Sonographische Darstellung eines soliden Granulosazelltumors.

Mean arterial blood pressure could be kept over $60 \mathrm{~mm} \mathrm{Hg}$ with or without administration of dobutamine. With the approaches described above, all the ovaries could be exteriorised and the mesovarium was dissected extraabdominally following ligation.

Recovery from anaesthesia was uneventful except in one mare which developed severe clinical and blood chemical signs of rhabdomyolysis. Routine medication described above was added by massive infusion of Ringers solution until the symptoms subsided.

Moderate abdominal pain was evident in seven mares the day following surgery. One of the mares died two days after surgery as the result of peracute typhlocolitis. Another mare developed severe intra-abdominal haemorrhage with hypovolemic shock and coagulapathia within 12 hours following 
laparotomy. This mare died despite blood transfusion and initiation of surgical haemostasis. During a post mortem examination, the large vessels between the muscles of the abdominal wall were identified as the origin of the haemorrhage, whereas the amputation stump was without specific findings. Healing of the laparotomy incision was uncomplicated except for the formation of seroma or transient serosanguineous incisional drainage in nine of the mares. No signs of wound dehiscence, incisional herniation or peritonitis were obvious during the hospital stay. Ten days after surgery, neither intraabdominal adhesions nor incisional herniation could be detected in any of the mares. The mares were released from the clinic 10 to 18 days following surgery except of three cases.

The diameter of the resected ovaries ranged between 11 and $45 \mathrm{~cm}$, with a maximum weight of $12.5 \mathrm{~kg}$.

The results of the patho-histological examination of the ovaries are given in Table 1. The granulosa cell tumour was the most common ovarian disorder in this study.

Follow-up results

Follow-up results were obtained by telephone contact with the owners of 32 of the 41 discharged mares. Normalisation of behaviour was registered in 28 of the 32 mares and in all the mares with resection of a granulosa cell tumour after surgery. Further attempts to breed were carried out with 16 of the 32 mares and were successful with 14 mares conceiving and

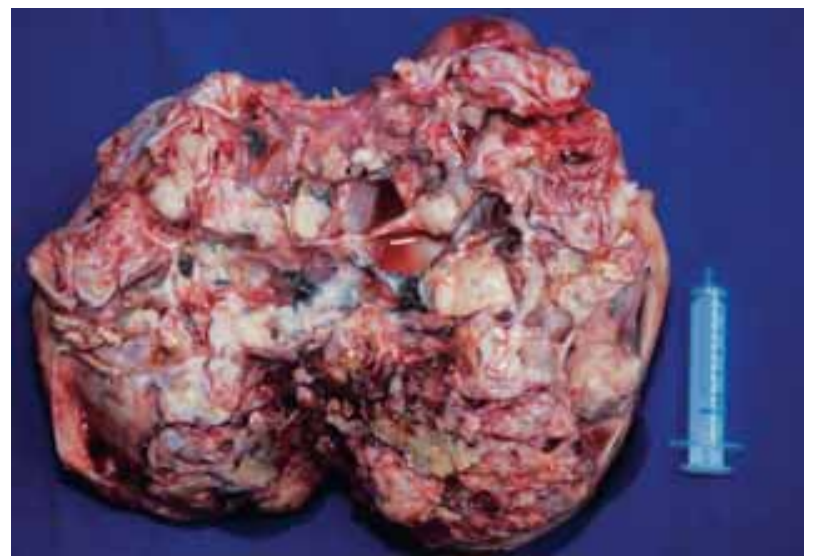

Fig 4 Malignant teratoma in mare No.36.

Malignes Teratom der Stute Nr. 36.

achieving term up to three years following surgery. The total number of foals per dam following unilateral ovariectomy ranged between one and four in this study. Thirteen of the 27 seven mares with granulosa cell tumour were not inseminated or mated despite the development of a normal sexual cycle postoperatively. Without exception, those horses were judged by the owners to show a sudden improvement in behaviour and utilisation as riding horses after surgery. Detailed information on the follow-up results can be found in Table 2 .

\section{Discussion}

Surgical therapy of ovarian disorders performed as unilateral ovariectomy remains major surgery with potential risks. The complications associated with ovariectomy and hysterectomy in the mare have been reported to be higher than those for other types of elective abdominal surgery: excessive haemor- rhage, myositis, paresis, peritonitis, wound dehiscence and diarrhea are the most commonly reported complications (Meagher et al 1978; Nickels 1988; Slone 1988), underlining the importance of intensive clinical postoperative monitoring.

In this study, rhabdomyolysis was seen in only one of the cases. This was a result of correct positioning of the mares, relatively short surgery time and adequate anaesthetic management. Intraoperative peripheral circulation was supported by routine infusion of crystalloid fluids and administration of dobutamine if necessary to obtain a mean arterial blood pressure of more than $60 \mathrm{~mm} \mathrm{Hg}$. The previously reported marked reduction in arterial blood pressure when the ovarian pedicle is under tension (Meagher et al. 1978) was not observed in any of the mares with or without administration of dobutamine. On the contrary, there was an average increase of arterial blood pressure during exteriorisation of the neoplastic ovaries.

Nevertheless, maximum care must be taken to avoid not only intra- but also postoperative complications, because there is an elevated risk of complications in mares following ovariectomy while recovering from anaesthesia (Bartmann et al. 1999; Glitz et al. 2001). Thus, postanaesthetic sedation following inhalation anaesthesia with halothane or isoflurane is recommended (Glitz et al. 2001; Bienert et al. 2003).

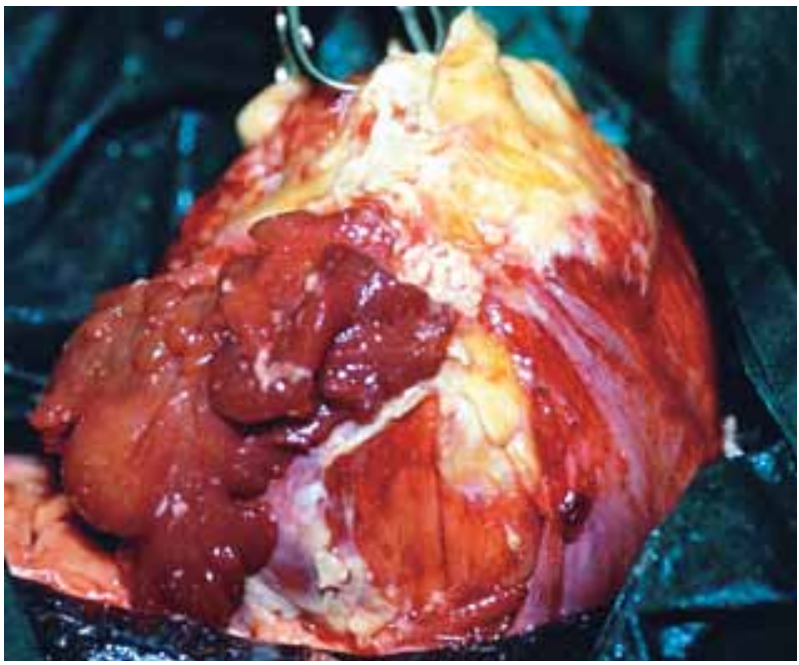

Fig 5 Intraoperative findings in mare No. 45 with an ovarian abscess. Severe oophoritis and generalized peritonitis. Intraoperativer Befund bei Stute Nr. 45 mit Ovarabszeß. Hochgradige Oophoritis und generalisierte Peritonitis.

Despite all prophylaxis, two of the mares in this study died because of haemorrhage or typhlocolitis. The exact aetiology of this severe enteropathia is still unclear, but the influence of stress, food-withdrawal, intra-abdominal surgery, antibiotic treatment and association with pathogenic clostridia (particularly Clostridium difficile) have been proposed. An initial dysbiosis of the intestinal microflora with decreasing colonisation resistance predisposes to an involvement of Clostridium difficile, possibly as a nosocomial infection. For this reason, intense attention should be paid to adequate hygiene, food should not be withheld for more than 6 to 12 hours preoperatively and the intestinal microflora should be maintained and stabilised by oral administration of probiotics. 
Although the diameter and weight of the neoplastic ovaries was relatively high in most cases, the flank approach with a modified grid technique was the preferred surgical approach due to its excellent adaptation of the abdominal obliquus muscle. Laparoscopic ovariectomy was the method of choice in only a few cases mainly because of the extensive size and weight of the diseased ovaries. Röcken (2000) however suggests a laparoscopic dissection of the mesovarium of neoplastic ovaries followed by its collection via a median laparotomy. Exteriorization of the ovaries while using a flank approach was practicable and secure step-by-step ligation of the mesovarium and the blood vessels could be performed. The origin of the only haemorrhage was the abdominal wall. The use of an ecraseur or an emasculator for haemostasis should be avoided. Damage to the tissue elevates the risk of intraabdominal adhesions.

Tab 2 Follow-up results with regard to further breeding, fertility, foaling rates, behaviour and riding performance in 32 mares following unilateral ovariectomy

Langzeitergebnisse von 32 Stuten nach unilateraler Ovariektomie bezüglich weiterer Zuchtverwendung, Fertilität, Abfohlrate, Verhalten und Reitleistung nach unilateraler Ovariektomie.

\begin{tabular}{|l|c|c|c|c|c|c|}
\hline \multirow{2}{*}{ Diagnosis } & \multicolumn{7}{|c|}{ Total } & $\begin{array}{c}\text { Normalization } \\
\text { of behaviour }\end{array}$ & $\begin{array}{c}\text { Breeding } \\
\text { use }\end{array}$ & Mares foaling & Riding use & $\begin{array}{c}\text { Improved } \\
\text { riding } \\
\text { performance }\end{array}$ \\
\hline $\begin{array}{l}\text { Granulosa } \\
\text { cell tumour }\end{array}$ & 27 & 27 & 14 & 13 & 13 & 13 \\
\hline $\begin{array}{l}\text { Teratoma } \\
\text { Ovarian } \\
\text { hematoma }\end{array}$ & 1 & - & 1 & 1 & 0 & 0 \\
\hline $\begin{array}{l}\text { Ovarian } \\
\text { dystrophy }\end{array}$ & 2 & 2 & 0 & 0 & 2 & 2 \\
\hline $\begin{array}{l}\text { Luteinized } \\
\text { cyst }\end{array}$ & 1 & 0 & 1 & 0 & 1 & 0 \\
\hline total & 32 & 28 & 16 & 14 & 16 & 15 \\
\hline
\end{tabular}

The most common ovarian neoplasia, the granulosa cell tumour, varies widely in its clinical and sonographic appearance (Hinrichs and Hunt 1990; Watson 1999). Typical symptoms are unilateral ovarian enlargement, contralateral ovarian atrophy and elevated levels of serum testosterone and estradiol. Although such patients were common in this study presented, there were also mares without clinically or endocrinologically clear signs of a granulosa cell tumour. In 13 mares with a diagnosis of a granulosa cell tumour subsequently confirmed histologically, there were no endorinological symptoms of a hormonally active neoplasia if in comparison to normal values of serum testosterone levels below $0.04 \mathrm{ng} / \mathrm{ml}$ or estradiol below $30 \mathrm{pg} / \mathrm{ml}$ according to Hoppen (1995). Thus, exclusion of granulosa cell tumour is not possible by means of endocrinological examination.

Furthermore, behaviour can be unsuspicious in those horses and in a some cases the contralateral ovary is of normal size with regular follicular activity. In agreement with the findings of Hinrichs et al. (1990), such a phenomenon was obvious in this study in mares Nos. 4, 6, 21 and 29 (Table 1).

On the other hand, the elevated levels of peripheral steroids decreased suddenly after surgery and returned to base-like levels ten days later without exception.

Even without laboratory documentation of endocrinological activity a granulosa cell tumour may inhibit the liberation of gonadotropic hormones from the hypophysis and may produce substances with an endocrine and paracrine effect such as dimeric inhibin (Bailey et al. 1998). Endometrium biopsy specimens are sensitive indicators of ovarian hormonal balance or imbalance. Endometrial maldifferentiation was a typical finding in mares in this study with a granulosa cell tumour, and this underlines the diagnostic value of endometrial biopsy, particularly in horses with clinically doubtful ovarian neoplasia.

In addition to decreasing levels of formerly elevated peripheral steroids, endometrial differentiation becomes regular following ovariectomy. This confirms the own clinical findings of reversibility of preoperative irregularities in fertility and behaviour and is in agreement with Meinecke (1986) and Meagher et al. (1978).

Resolution of abnormal behaviour became apparent during the hospital stay. The return to a regular sexual cycle normally requires weeks or months and varies greatly.

In consideration of the results shown in Table 2, prognosis for further utilisation of a mare with regard to fertility or riding performance is excellent following resection of a granulosa cell tumour.

In conclusion, ovariectomy remains a serious surgical procedure in the mare but complications can be markedly reduced by adequate surgical and anaesthetic management in combination with clinical and laboratory evaluation following surgery. Reestablishment of fertility following unilateral ovariectomy and resolution of preoperative clinical signs justify such a treatment, particularly when complications can be prevented or managed succesfully.

\section{Literature}

Bailey M. T., S. A. Christman, J. E. Wheaton, M. H. T. Troedsson, T. D. O'Brien, M. M. Ababneh and E. Santschi (1999): Inhibin localisationin equine Granulosa-theca cell tumours and inhibin forms in tumour fluid. Proc. $7^{\text {th }}$ Int. Symp. Equine Reprod., Pretoria 12.17.07.98, 65-66

Bartmann C. P. , and K. J. Lorber (in press): Laparoscopic gonadectomy in two half-sister horses with male pseudohermaphroditism of the testicular feminisation type. Equine vet. Educ.

Bartmann C.., K. Lorber, M. Wachholz, I. Brickwedel and E. Klug (1999): Complications of ovariectomy and hysterectomy in the mare - prevention, diagnosis, management. Vet. Surg. 28, 206

Bienert A., C. P. Bartmann, T. v. Oppen, C. Poppe, V. Schiemann und E. Deegen (2003): Aufstehverhalten bei Pferden nach Inhalationsnarkose mit Isofluran (Isoflo ${ }^{\circledR}$ ) und postanästhetischer Sedierung mit Romifidin $\left(\right.$ Sedivet ${ }^{\circledR}$ ) bzw. Xylazin (Rompun ${ }^{\circledR}$ ). Dtsch. Tierärztl. Wschr. 110, 244-248

Carson-Dunkerley S. A. and R. Reid-Hanson (1997): Ovariectomy of granulosa cell tumors in mares by use of the diagonal paramedian approach: 12 cases (1989-1995). J. Am. Vet. med. Ass. 211 , 204-206

Ellenberger C., H. Aupperle, C. P. Bartmann, H.-O. Hoppen, D. Schoon and H.-A. Schoon (2002): Endometrial maldifferentiation caused by ovarian disorders in the mare - morphological and immunohistochemical studies. Theriogenology 58, 499-502

Gerhards H. (1991): Low dose calcium heparin in horses: plasma heparin concentrations, effects on red blood cell mass and on coagulation variables. Equine vet. J. 23, 37-43

Glitz F., K. Lorber, T. v. Oppen, K. Bubeck, C. P. Bartmann and E. Deegen (2001): Aufstehverhalten von Pferden nach Inhalationsnarkose mit und ohne postanästethische Sedierung mit Xylazin (Rompun $\left.{ }^{\circledR}\right)$.Pferdeheilkunde 17, 165-172 
Herfen K., H. Bostedt, G. Schuler and M. Weil (1996): Ovartumore und tumorähnliche Zustände bei Stuten. Reprod. 31, Dom. Anim., 65

Hinrichs K. and P. R. Hunt (1990): Ultrasound as an aid to diagnosis of granulosa cell tumour in the mare. Equine vet. J., 22, 99-103

Hinrichs K., E. Watson and R. M. Kenney (1990): Granulosa cell tumour in a mare with a functional contralateral ovary. J. Am. Vet. med. Ass., 197, 1037-1038

Hoppen H. O. (1995): Endocrine diagnostic techniques in equine reproduction. Reprod. Dom. Anim. 30, 149-152

Meagher D. M., J. D. Wheat, J. P. Hughes, G. H. Stabenfeldt and B. A. Harris (1978): Granulosa cell tumors in mares - a review of 78 cases. Proc. Am. Ass. Equine Pract.133-143

Meinecke B. (1986): Zur Klinik der Ovartumoren der Stute. Tierärztl. Prax. 14, 501-508

Meinecke B. and H. Gips (1987): Steroid hormone secretory patterns in mares with granulosa cell tumours. J. Vet. Med. A. 34, 545-560

Nickels F. A. (1988): Complications of castration and ovariectomy. Vet. clin. North Am. Equine pract. , 4, 515-525

Palmer S. E. (1993): Standing laparoscopic laser technique for ovariectomy in five mares. J. Am. Vet. med. Ass. 203, 279-283

Röcken M. (2000): Laparoskopische Kryptorchidektomie und Ovariektomie am stehenden Pferd. Teil 2: Laparoskopische Ovariektomie. Prakt. Tierarzt 81, 34-42

Schoon H.-A., D. Schoon and E. Klug (1997): Die Endometriumbiopsie bei der Stute im klinisch-gynäkologischen Kontext. Pferdeheilkunde 13, 453-464
Schoon H.-A., D. Schoon, I. Wiegandt, C. P. Bartmann and H. Aupperle (1999): „Endometrial maldifferentiation" - A clinically significant diagnosis in equine reproduction? Pferdeheilkunde 15, 555-559

Schoon H.-A., I. Wiegandt, D. Schoon, H. Aupperle und C. P. Bartmann (2000): Functional disturbances of the equine endometrium. J. Reprod. Fertil. Suppl. 56, 381-391

Slone D. E. (1988): Ovariectomy, Ovariohysterectomy and Cesarean Section in Mares. Vet. clin. North Am. Equine pract. 4, 451461

Stabenfeldt G. H., J. P. Hughes, P. C. Kennedy, D. M. Meagher and D. P. Neely (1979): Clinical findings, pathological changes and endocrinological secretory patterns in mares with ovarian tumours. J. Reprod. Fert., Suppl. 27, 277-285

Valk N., E. W. Davis und J. T. Blackford (1998): Ovarian torsion as a cause of colic in a neonatal foal. J. Am. Vet. Med. Assoc. 213, 1454-1456

Watson E. D. (1999): Granulosa cell tumours in the mare: - a review of 9 cases. Equine vet. Educ. 1 1, 136-142

Dr. Claus Peter Bartmann

Einsatz- und Ausbildungszentrum für Gebirgstragtierwesen 230

Nonner Str. 25

D-83435 Bad Reichenhall

cpbartmann@gmx.de 